\title{
Determinan Perilaku Konsumsi Makanan Siap Saji (Fast Food) Pada Siswa di SMA Negeri X Jakarta Timur Tahun 2020
}

\author{
Samingan, Zalita Azwalika Octaviani \\ Program Studi Kesehatan Masyarakat, Fakultas IImu Kesehatan \\ Universitas Respati Indonesia \\ Email : saminganmingan76@yahoo.co.id
}

\begin{abstract}
Abstrak
Makanan siap saji (fastfood) merupakan hidangan praktis dan gampang dalam pengolahannya dengan mengandung tinggi lemak, tinggi garam tetapi rendah serat. Tujuan penelitian ini adalah mengetahui faktor-faktor yang berhubungan dengan perilaku konsumsi makanan siap saji pada siswa di SMA Negeri X Jakarta Tahun 2019. Penelitian ini meggunakan metode penelitian observasi dengan desain penelitian cross sectional dengan menggunakan instrumen penelitian berupa kuesioner. Total populasi dalam penelitian ini adalah 500 responden dan total sampel yang digunakan dalam penelitian ini adalah 226 responden dengan teknik random sampling. Hasil dalam penelitian ini adalah terdapat hubungan antara pengaruh teman sebaya (nilai $p=0,001$ ), uang saku (nilai $p=0,001$ ) dan dukungan orang tua (nilai $p=0,027$ ) dengan perilaku konsumsi makanan siap sa ji (fast food) pada siswa di SMA Negeri X Jakarta Tahun 2019. Disimpulkan ada hubungan antara pengaruh teman sebaya, uang saku, dukungan orang tua dengan perilaku konsumsi makanan siap saji. Maka disarankan perlu dilakukan sosialisasi kepada orang tua siswa di sekolah untuk mengontrol uang saku dan selalu membawa bekal untuk siswa kesekolah, serta diadakan kegiatan penyuluhan kesehatan bagi siswa tentang mengkonsumsi makanan siap saji dan makanan yang sehat dengan gizi seimbang.
\end{abstract}

Kata Kunci : Makanan siap saji, Perilaku, Siswa.

\begin{abstract}
Fast food is a practical dish and easy to process with high fat, high salt but low in fiber. The purpose of this study was to determine the factors associated with the behavior of fast food consumption in students at X high school Jakarta in 2019. This study used a observational research method with cross sectional research design using a questionnaire research instrument. The total population in this study was 500 respondents and the total sample used in this study was 226 respondents with random sampling technique. The results in this study are that there is a relationship between peer influence $(p=0,000)$, pocket money $(p=0,000)$ and parental support $(p=$ 0.027) with fast food consumption behavior among $X$ high school students Jakarta in 2019. It was concluded that there was a relationship between peer influence, pocket money, parent support and fast food consumption behavior. It is recommended that socialization be given to parents of students at school to control pocket money and always bring provisions for students to school, as well as health education activities for students about eating fast food and healthy foods with balanced nutrition.
\end{abstract}

Keywords: Fast food, Behavior, Students.

http://ejournal.urindo.ac.id/index.php/kesehatan

Article History :

Sumbitted 13 Desember 2021 Accepted 30 Desember 2021, Published 31 Desember 2021 


\section{PENDAHULUAN}

Health Education Authority pada tahun 2012, pada usia 15-34 tahun terjadi tingginya untuk mengkonsumsi fast food. Terjadinya kejadian ini dapat dilihat dari munculnya berbagai kedai yang menyajikan makanan siap saji, seperti seperti ayam goreng tepung, sosis bakar, kebab, burger, soft drink dan lain-lain. ${ }^{1}$

World Health Organizatiom (WHO) tahun 2016 menyatakan bahwa junk food adalah yang mengandung jumlah lemak yang besar, garam, gula, kalori dan rendah nutrisi, vitamin, mineral dan serat. Makanan tersebut seperti fast food, gorengan, makanan kaleng, soft drink, permen, asinan hingga snacks (makanan ringan). ${ }^{1}$

Berdasarkan penelitian di Bangladesh, siswa yang mengkonsumsi makanan siap saji (fast food) sebanyak $\geq 2$ hari per minggu dengan risiko 2,2 kali untuk mengalami obesitias. $^{2}$ Selain itu, penelitian lain menunjukkan bahwa $90 \%$ yang mengkonsumsi makanan siap saji (fast food), mengalami pre obesitas 22,45\% dan 9,52\% mengalami obesitas. $^{3}$ Sebanyak 54,40 \% siswa menyukai makanan siap saji (fast food) dan lebih dari $60 \%$ siswa tidak menyadari mengenai fakta bahwa makanan siap saji (fast food) adalah makanan yang tidak sehat. ${ }^{4}$

Hasil survei yang dilakukan oleh Lemia dan Dalal (2019) pada bulan Januari - Maret 2016 mengenai tren konsumsi makanan siap saji di kalangan pemuda Kuwait dengan 421 siswa diantaranya 297 wanita dengan usia rata-rata 14 tahun - 20 tahun, sebagian besar $81,4 \%$ mengkonsumsi makanan siap saji lebih dari dua kali per minggu dan lebih banyak pria $(54,8 \%)$ dari pada wanita yang kelebihan berat badan atau obesitas $(38,7 \%)$. Namun tidak ada perbedaan dalam frekuensi makanan siap saji per indeks massa tubuh atau jenis kelamin. Rasa merupakan motivator yang paling banyak dilaporkan untuk mengkonsumsi makanan siap saji $(46,7 \%)$ dan $49,8 \%$ wanita secara signifikan lebih cenderung menilai rasa dibandingkan pria yaitu $38,9 \%{ }^{5}$

Global School Health Survey tahun 2015, tergambarnya pola makan pada remaja bahwa remaja yang tidak pernah sarapan $(65,2 \%)$, kurang mengkonsumsi sayur dan buah $(93,6 \%)$ dan sering konsumsi makanan berpenyedap $(75,7 \%)$. Diantaranya kurang melakukan aktifitas fisik (42,5\%). Jika cara konsumsi seperti ini berlangsung secara terus menerus dan menjdi suatu kebiasaan pola makan para remaja, maka akan meningkatkan resiko penyakit tidak menular. ${ }^{6}$

Berdasarkan studi pendahuluan yang dilakukan di SMA Negeri X Jakarta kepada 20 siswa terdapat 15 siswa sering mengkonsumsi makanan siap saji dan 5 siswa terkadang mengkonsumsi makanan siap saji dengan jajan 
di kantin sekolah. Sekolah membiasakan para siswa/siswinya untuk selalu membawa bekal ke sekolah dan terdapat $1 \%$ siswa yang tidak pernah membawa menu makanan siap saji pada bekalnya, 90\% siswa membawa bekal dengan diantaranya 10\% siswa terkadang membawa bekal dengan menu makanan siap saji, berdasarkan latar belakang tersebut bahwa perilaku konsumsi makanan siap saji pada siswa tersebut diasumsikan ada hubungannya dengan, jenis kelamin, pengetahuan, sikap, dukungan kelurga, teman sebaya, dan uang saku. Tujuan penelitian ini adalah mengetahui faktor-faktor yang berhubungan dengan perilaku konsumsi makanan siap saji pada siswa di SMA Negeri $X$ Jakarta Tahun 2019.

\section{METODE}

Jenis penelitian ini menggunakan bersifat observasi dengan desain penelitian cross sectional untuk melihat faktor-faktor yang berhubungan dengan perilaku makanan siap saji. Populasi dalam penelitian ini adalah siswa kelas X dan XI yang berjumlah 500 responden. Sedangkan jumlah sampel yang ada 226 sampel, tekni pengangbilan sampling pada peneltian ini denga porposif sampling. Pengumpulan data dilakukan dengan menggunakan kuesioner untuk mendapatkan data mengenai pengetahuan, sikap, pengaruh teman sebaya, uang saku, dukungan orang tua, jenis kelamin. Data yang telah terkumpul akan dianalisis menggunakan uji chi square univarit dan bivariate dengan uji korelasi.

\section{HASIL DAN PEMBAHASAN}

\section{Analisis Univariat}

Tabel 1 menunjukkan distribusi karakteristik berdasarkan perilaku, pegetahuan, sikap, pengaruh teman sebaya, dukungan orang tua, uang saku dan jenis kelain.

Tabel 1. Distribusi karakteristik berdasarkan perilaku, pengetahuan, sikap, pengaruh teman sebaya, dukungan orang tua, uang saku dan jenis kelamin.

\begin{tabular}{|l|c|c|}
\hline \multicolumn{1}{|c|}{ Variabel } & Frekuensi & $\%$ \\
\hline Perilaku & & \\
\hline Baik & 89 & 39,4 \\
\hline Kurang baik & 137 & 60,6 \\
\hline Pengetahuan & & \\
\hline Rendah & 55 & 24,3 \\
\hline Tinggi & 171 & 75,7 \\
\hline Sikap & & \\
\hline Positif & 137 & 61,5 \\
\hline Negatif & 87 & 38,5 \\
\hline Pengaruh Teman Sebaya & & \\
\hline Tidak ada pengaruh & 77 & 34,1 \\
\hline Ada pengaruh & 149 & 65,9 \\
\hline Dukungan Orang Tua & & \\
\hline Ada dukungan & 143 & 63,3 \\
\hline Tidak ada dukungan & 83 & 36,7 \\
\hline Uang Saku & & \\
\hline Kecil & 58 & 25,7 \\
\hline Besar & 168 & 74,3 \\
\hline Jenis Kelamin & & \\
\hline Laki-Laki & 92 & 40,7 \\
\hline Perempuan & & 59,3 \\
\hline
\end{tabular}


Bahwa dari siswa yang memiliki perilaku kurang baik didapatkan 137 responden $(60,6 \%)$ sedangkan 89 responden $(39,4)$. Untuk responden dengan pengtahuan tinggi yaitu 171 responden $(75,7 \%)$ dan pengetahuan rendah 55 responden $(24,3 \%)$. Untuk siswa yang memiliki sikap yang positif yaitu 137 responden $(61,5 \%)$ sedangkan sikap negatif 87 responden (38,5\%). Untuk pengaruh teman sebaya yaitu siswa yang ada pengaruh dari teman sebaya yaitu 149 responden (65,9\%) dan tidak ada pengaruh teman sebaya ada 77 responden $(34,1 \%)$. Untuk siswa yang memiliki uang saku besar ada 168 responden $(74,3 \%)$ sedangkan uang saku kecil adalah 58 responden (25,7\%). Siswa perempuan ada 134 responden (59,3\%) dan untuk siswa laki-laki ada 92 (40,7\%).

\section{Analisis Bivariat}

Analisis bivariat yang dilakukan terhadap dua variabel yang diduga berhubungan atau berkorelasi antara variabel independen dengan dependen, seperti (pengetahuan, sikap, pengaruh teman sebaya, dukungan orang tua, uang saku dan jenis kelamin) dengan perilaku konsumsi makanan siap saji di SMA Negeri X Jakarta Tahun 2019. Hasil analisis bivariat dapat dilihat pada tabel 2 .

Tabel 2. Faktor-faktor yang berhubungan dengan perilaku konsumsi makanan siap saji

(fast food) di SMA Negeri X Jakarta

\begin{tabular}{|c|c|c|c|c|c|c|c|c|c|}
\hline \multirow{3}{*}{ Variabel } & \multirow{3}{*}{ Frekuensi } & \multirow{3}{*}{ Presentase } & \multicolumn{4}{|c|}{ Perilaku Konsumsi Makanan } & \multirow{3}{*}{ Nilai $\mathbf{P}$} & \multirow{3}{*}{$\begin{array}{l}\text { Odds } \\
\text { Rasio }\end{array}$} & \multirow{3}{*}{$95 \% \mathrm{CI}$} \\
\hline & & & \multicolumn{2}{|c|}{ Baik } & \multicolumn{2}{|c|}{ Kurang Baik } & & & \\
\hline & & & $\mathbf{n}$ & $\%$ & $\mathbf{n}$ & $\%$ & & & \\
\hline \multicolumn{10}{|l|}{ Pengetahuan } \\
\hline Rendah & 55 & 24,3 & 21 & $38,20 \%$ & 34 & $61,80 \%$ & \multirow{2}{*}{0,96} & \multirow{2}{*}{0,936} & $0,501-$ \\
\hline Tinggi & 171 & 75,7 & 68 & $39,80 \%$ & 103 & $60,20 \%$ & & & 1,747 \\
\hline \multicolumn{10}{|l|}{ Sikap } \\
\hline Negatif & 87 & 38,5 & 28 & $32,20 \%$ & 59 & $67,80 \%$ & \multirow{2}{*}{0,107} & \multirow{2}{*}{0,607} & $0,346-$ \\
\hline Positif & 137 & 61,5 & 61 & $43,90 \%$ & 78 & $56,10 \%$ & & & 1,063 \\
\hline \multicolumn{10}{|c|}{ Pengaruh Teman Sebaya } \\
\hline Ada pengaruh & 149 & 65,9 & 42 & $28,20 \%$ & 107 & $71,80 \%$ & \multirow{2}{*}{0,000} & \multirow{2}{*}{3,911} & $2,233-$ \\
\hline Tidak ada pengaruh & 77 & 34,1 & 47 & $61,00 \%$ & 30 & $39,00 \%$ & & & 7,133 \\
\hline \multicolumn{10}{|c|}{ Dukungan Orang Tua } \\
\hline Tidak ada dukungan & 83 & 36,7 & 41 & $49,40 \%$ & 42 & $50,60 \%$ & \multirow{2}{*}{0,027} & \multirow{2}{*}{1,932} & \\
\hline Ada dukungan & 143 & 63,3 & 48 & $33,60 \%$ & 95 & $66,40 \%$ & & & 3,358 \\
\hline \multicolumn{10}{|l|}{ Uang Saku } \\
\hline Kecil & 58 & 25,7 & 35 & $60,30 \%$ & 23 & $39,70 \%$ & \multirow{2}{*}{0,000} & \multirow{2}{*}{3,213} & $1,732-$ \\
\hline Besar & 168 & 74,3 & 54 & $32,10 \%$ & 114 & $67,90 \%$ & & & 5,958 \\
\hline \multicolumn{10}{|l|}{ Jenis Kelamin } \\
\hline Laki-Laki & 92 & 40,7 & 41 & $44,60 \%$ & 51 & $55,40 \%$ & \multirow{2}{*}{0,237} & \multirow{2}{*}{1,440} & $0,838-$ \\
\hline Perempuan & 134 & 59,3 & 48 & $35,80 \%$ & 86 & $64,20 \%$ & & & 2,477 \\
\hline
\end{tabular}


Perilaku merupakan sebuah respon ataupun reaksi seseorang terhadap suatu stimulus (rangsangan dari luar). ${ }^{7}$ Perilaku dipengruhi oleh bberapa faktor, dalam penelitian ini mengambil beberapa faktor diantaranya jenis kelamin, pengetahuan, sikap, uang saku, pengaruh teman sebaya serta orang tua. ${ }^{8}$ Berdasarkan hasil univariat diperoleh bahwa distribusi frekuensi perilaku siswa dalam konsumsi makanan siap saji di SMA Negeri X Jakarta diperoleh lebih dari setengah responden memiliki perilaku yang kurang baik dalam mengkonsmsi makanan siap saji sebanyak 137 siswa (60,6\%). Padahal kebiasaan konsumsi makanan siap saji secara terus menerus tidak baik untuk kesehatan.

Dari 226 siswa yang menjadi responden didapatkan pengetahuan dengan perilaku konsumsi makanan siap saji presentase siswa yang pengetahuan rendah $61,80 \%$ (34 responden).

Sedangkan pada siswa yang memiliki pengetahuan yang tinggi, ada 103 responden $(60,20 \%)$ dengan perilaku konsumsi makanan siap saji kurang baik. Hasil uji statistik diperoleh nilai- $p=0,960$, hal ini menunjukkan nilai $p>0,05$ maka dapat disimpulkan tidak ada hubungan yang signifikan antara pengetahuan dengan perilaku konsumsi makanan siap saji. Pengetahuan adalah hasil dari sebuah proses pembelajaran yang melibatkan beberapa indera, yaitu indera penglihatan, pendengaran, penciuman dan pengecapan. ${ }^{9}$ Pada penelitian ini terdapat 103 siswa berpengetahuan tinggi tetapi memiliki prilaku konsumsi makanan siap saji kurang baik. Pengetahuan makanan siap saji yang baik belum tentu membuat para siswa memiliki perilaku yang baik juga dan belum tentu siswa tidak menyukai makanan siap saji.

Hubungan sikap dengan perilaku konsumsi makanan siap saji di SMA Negeri $X$ Jakarta yang memiliki sikap negatif sebanyak 59 responden (67,80\%). Sedangkan diantara siswa yang memiliki sikap positif ada 78 responden (56,10\%) dengan perilaku konsumsi makanan siap saji kurang baik. Hasil uji statistik diperoleh nilai-p $=0,107$, hal ini menunjukkan nilai $\mathrm{p}>0,05$ maka dapat disimpulkan tidak ada hubungan yang signifikan antara sikap dengan perilaku konsumsi makanan siap saji.

Suatu respon yang tertutup terhadap objek tertentu atau stimulus pada seseorang yang melibatkan faktor pendapat dan emosi pada seseorang seperti senang tidak senang, setuju-tidak setuju, baik-tidak baik dan sebagainya. ${ }^{7}$ Pada penelitian ini, siswa yang memiliki sikap negatif ada 59 siswa $(67,8 \%)$ 
sedangkan sikap positif ada 78 siswa $(56,10 \%)$. Siswa yang memiliki sikap positif belum tentu memiliki perilaku baik dalam konsumsi makanan siap saji, meskipun siswa mengetahui bahwa mengkonsumsi makanan siap saji tidak baik untuk kesehatan.

Hubungan pengaruh teman sebaya dengan perilaku konsumsi makanan siap saji di SMA Negeri X Jakarta, sebanyak 107 responden $(71,80 \%)$ ada pengaruh teman sebaya. Sedangkan diantaranya ada 30 responden $(39,00 \%)$ yang tidak ada pengaruh dari teman sebaya dengan perilaku kurang baik dalam konsumsi makanan siap saji. Hasil uji statistik diperoleh nilai- $p=0,000$. Maka, ada hubungan yang signifikan antara pengaruh teman sebaya dengan perilaku konsumsi makanan siap saji. Diperoleh pula nilai $\mathrm{OR}=$ 3,911 , artinya siswa yang tidak ada pengaruh dari teman sebaya mempunyai kecenderungan sebesar 3,9 kali untuk mengalami perilaku konsumsi makanan siap saji. Maka, siswa yang tidak ada pengaruh dari teman sebaya dibandingkan degan siswa yang memiliki pengaruh dari teman sebaya 2,2 7,1 kali untuk terjadinya konsumsi makanan siap saji.

Memiliki banyak aktifitas diluar rumah membuat remaja sering dipengaruhi oleh teman sebayanya. Pemilihan makanan tidak lagi didasarkan oleh kandungan gizi tetapi sekedar untuk bersosialisasi kesenangan dan untuk tidak kehilangan status. ${ }^{10}$ Siswa bergaul disekolah dengan cara bersosialisasi dengan teman sebayanya. Bersosialisasi dengan teman sebaya membuat siswa sering mengajak atau bahkan mengajak teman sebayanya untuk membeli hingga mengkonsumsi makanan siap saji.

Hubungan dukungan orang tua dengan perilaku konsumsi makanan siap saji di SMA Negeri X Jakarta, ada sebanyak 42 siswa (50,60\%) tidak ada dukungan orang tua. Diantaranya ada 95 siswa $(66,40 \%)$ adanya dukungan orang tua dengan perilaku konsumsi makanan siap saji yang kurang baik. Hasil uji statistik diperoleh nilai $p=0,027$ maka ada hubungan yang signifikan antara dukungan orang tua dengn perilaku konsumsi makanan siap saji. Diperoleh pula nilai $O R=$ 1,932 , artinya siswa yang tidak ada dukungan dari orang tua mempunyai kecenderungan sebesar 1,9 kali untuk mengalami perilaku konsumsi makanan siap saji. Maka, siswa yang tidak mendapatkan dukungan orang tua dibandingkan dengan siswa yang mendapat dukungan sebesar 1,1 - 3,3 kali lebih besar untuk mengkonsumsi makanan siap saji.

Orang tua memiliki peran yang sangat berpengaruh terhadap kebiasaan pola makan 
anak dan asupan gizi anak. Peran orang tua yang berhubungan dengan status gizi anak, dimana semakin tinggi peran orang tua maka status gizi anak akan semakin baik atau gizi normal, namun sebaliknya jika peran orang tua semakin rendah maka anak akan mengalami gizi lebih atau obesitas dan overweight. ${ }^{11}$ Dalam hal ini, orang tua menjadi panutan anak nya mengenai kebiasaan memakan makanan yang baik sehingga berdampak pada pola makan anak yang baik.

Orang tua memiliki peran yang sangat penting bagi siswa, terutama asupan makanan yang dikonsumsi oleh siswa. karena, sebagian besar siswa yang ada di SMA Negeri X Jakarta mendapatkan dukungan orang tua dalam mengkonsumsi makanan siap saji. Makanan siap saji merupakan makanan yang paling cepat dan simple dari cara pemasakana nya jika untuk disajikan dalam waktu yang cepat, sehingga membuat orang tua lebih tertarik pada menu makanan siap saji karena praktis untuk hidangkan.

Hubungan uang saku dengan perilaku konsumsi makanan siap saji di SMA Negeri $X$ Jakarta diperoleh ada sebanyak 23 siswa $(39,70 \%)$ memiliki uang saku kecil. Diantaranya ada 114 siswa (67,90\%) uang saku besar dengan perilaku konsumsi makanan siap saji yang kurang baik. Hasil uji statistik diperoleh nilai P. Value $=0,000$. Maka, ada hubungan yang signifikan antara uang saku dengan perilaku konsumsi makanan siap saji. Dari hasil analisis diperoleh pula nilai $\mathrm{OR}=$ 3,213 artinya siswa yang uang saku besar mempunyai kecenderungan sebesar 3,2 kali untuk mengalami perilaku konsumsi makanan siap saji. Maka, siswa yang mendapat uang saku kecil dibandingkan dengan siswa yang mendapat uang saku besar memiliki 1,7 - 5,9 kali untuk mengkonsumsi makanan siap saji.

Penelitian ini sejalan dengan penelitian Mahpolah, dkk (2016), hasil uji statistik menggunakan uji korelasi spearman menunjukkan ada hubungan yang bermakna antara jumlah uang saku dengan kebiasaan konsumsi makanan siap saji pada remaja di SMA Kartika V-1 Balikpapan dengan nilai koefisien korelasinya ( $r$ ) adalah -0,262. Menunjukkan keeratan hubungan antara jumlah uang saku remaja dengan kebiasaan konsumsi makanan siap saji mempunyai hubungan yang sedang. ${ }^{12}$

Semakin besar uang saku yang diterima seseorang maka semakin besar pula kualitas dan kuantitas makanan yang dikonsumsinya. ${ }^{13}$ Uang saku yang dimiliki oleh siswa memiliki pengaruh dalam mengkonumsi makanan siap saji. Karena semakin besar uang saku yang dimiliki, semakin besar pula peluang 
siswa untuk lebih sering megkonsumsi makanan siap saji.

Hubungan jenis kelamin dengan perilaku konsumsi makanan siap saji di SMA Negeri $X$ Jakarta diperoleh bahwa ada sebanyak 51 siswa $(55,40 \%)$ yang berjenis kelamin laki-laki dengan perilaku konsumsi makanan siap saji kurang baik. Sedangkan diantaranya ada 86 siswa $(64,20 \%)$ berjenis kelamin perempuan dengan perilaku konsumsi makanan siap saji yang kurang baik. Hasil uji statistik diperoleh nilai $p=0,237$ maka hal ini menunjukkan nilai $p>0,05$ dapat disimpulkan tidak ada hubungan yang signifikan antara jenis kelamin dengan perilaku konsumsi makanan siap saji. Penelitian ini sejalan dengan penelitian Ika Suswanti (2013) diperoleh hasil tidak ada hubungan yang signifikan antara jenis kelamin (nilai $p=0,063$ ), pengetahuan (nilai $p=0,570$ ), pendapatan(nilai $p=0,600$ ), rasa (nilai $p=0,406$ ), tekstur(nilai $p=0,181$ ), bentuk(nilai $p=0,744$ ), bumbu (nilai $p=0,382$ ), harga (nilai $p=0,346)$ dengan pemilihan makanan siap saji. $^{14}$

Tidak adanya hubungan antara jenis kelamin dengan perilaku konsumsi makanan siap saji, dimungkinkan karena proporsi perempuan yang ikut dalam penelitian ini lebih banyak dari pada laki-laki, hal ini disebabkan karena siswa di SMA Negeri $\mathrm{X}$
Jakarta secara keseluruhan memang jauh lebih tinggi. Sehingga dalam pengambilan sampel, perempuan lebih memiliki banyak kesempatan untuk terpilih menjadi responden peneltian. Karena jumlah populasi perempuan lebih tinggi dibandingkan laki-laki yang ikut terlibat dalam penelitian, maka dimungkinkan laki-laki lebih konsumtif dalam mengkonsumsi makanan siap saji, karena dari 92 siswa laki-laki terdapat 51 siswa laki-laki berperilaku tidak baik dalam mengkonsumsi makanan siap saji.

\section{SIMPULAN}

Berdasarkan hasil penelitian mengenai faktor - faktor yang berhubungan dengan perilaku konsumsi makanan siap saji bahwa sebagian besar siswa dengan perilaku tidak baik dalam mengkonsumsi makanan siap saji sebesar 60,6\% (137 siswa). Pada variabel yang berhubungan yaitu pengaruh teman sebaya (nilai $p=0,000$ ), uang saku (nilai $p=0,000$ ) dan dukungan orang tua (nilai $p=0,027$ ). Pada variabel tidak berhubungan pada pengetahuan (nilai $p=0,936$ ), sikap (nilai $p=0,607$ ) dan jenis kelamin (nilai $p=0,237$ ).

Disarankan untuk melakukan sosialisasi kepada orang tua melalui pertemuan dengan komite sekolah terkait hasil penelitian dengan mengundang petugas kesehatan sebagai narasumber sosialisasi. Melalui pertemuan 
dengan komite sekolah agar dapat mendorong orang tua untuk menyiapkan bekal dengan menu yang bukan makanan siap saji (fast food). Melakukan kebijakan untuk menyediakan makanan yang sehat pada kantin sekolah dan diganti dengan kantin sekolah sehat dengn menu makanan seperti soto, ketoprak, burger dengan isi sayuran yang kaya akan serat, kebab ayam, roti, susu, telur, dll.

Merencanakan kegiatan makan siang bersama satu hari dalam seminggu, untuk mendorong siswa membawa bekal dengan menu sehat dan gizi seimbang. Disarankan untuk orang tua dapat membekali bekal makanan yang bukan makanan siap saji. Pembuatan makanan sesuai dengan kreasi ibu. Seperti, telur dadar di campur dengan daun kelor yang baik untuk kesehatan dan lain-lain. Untuk uang saku siswa, para orang tua harus bisa mempertimbangkan besaran uang saku yang harus diterima oleh siswa, supaya siswa tidak membeli makanan siap saji. Pihak sekolah sudah bekerja sama dengan puskesmas bahwa setiap hari jumat ada kegiatan free of Friday (free jentik, free anemia, free mal nutrisi). Pada kegiatan ini bisa diselipkan informasi mengenai makanan siap saji. Untuk para siswa agar tidak terpengaruh oleh teman sebaya yang lainnya. Penelitian ini dapat dijadikan sebagai masukan dan bahan untuk penelitian selanjutnya, peneliti selanjutnya juga dapat melakukan intervensi dan mengembangkan penelitian ini mengenai konsumsi makanan siap saji pada siswa di SMA Negeri X Jakarta.

\section{DAFTAR PUSTAKA}

[1]Pos Kota News. 52 Persen Warga Jakarta Sarapan dengan Junk food [serial on internet]. 2016 [cited 2019 Nov 04]. Available from: https:

//poskotanews.com/2016/08/17/52-

persen-warga-jakartasarapan -denganjunk-food/.

[2]Goon S, Bipasha MS, Islam Md. Fast food Consumption and Obesity Risk Among University Students of Bangladesh. Europan Journal of Preventive Medicine. 2014; Vol.2 : No.6.

[3] Shah T, Purohit G, Nair SP, Patel B, Rawal Y, Shah RM. Assessment of Obesity, Overweight and Its Association with The Fast food Consumption in Medical Students. Journal of Clinical and Diagnostic Research; 2014: Vol. 8 : No. 5.

[4] Purohit G, Shah T, Harsoda JM. Prevalence of Obesity in Medical Students and Its Correlation with Cardiovascular Risk Factors : Emergency Alarm for Today. Kathmandu University Mecidal Journal; 2015; Vol. 13 : No. 4. 
[5] Lemia S \& Dalal A. 2019. Trends in Fast food Consumption Among Kuwiti Youth. International Journal of Preventive Medicine; Vol. 10. $1^{\text {st }}$ ed,p.44 [serial on internet]. 2019 [cited 2019 Nov 01]. Available from: https:// www.ncbi.nlm.nih.gov/pmc/articles/PMC6 528418/.

[6] Kementrian Kesehatan. Remaja Indonesia Harus Sehat [serial on internet]. 2019 [cited 2019 Okt 27]. Available from:https://www.kemkes.go.id /article/view/18051600001/menkesremaja indonesia-hrus-sehat.html.

[7] Notoatmodjo S. Promosi Kesehatan dan Ilmu Perilaku. Jakarta: PT Rineka Cipta; 2005.

[8] Notoatmodjo S. Promosi Kesehatan dan Perilaku Kesehatan. Jakarta: PT. Rineka Cipta; 2012.

[9] Notoatmodjo S. Pendidikan Kesehatan dan Ilmu Perilaku. Jakarta: PT. Rineka Cipta; 2007.

[10] Khomsan A. Rahasia Sehat dengan Makanan Berkhasiat. Jakarta: Kompas; 2009.
[11] Sulistyoningsih H. Gizi Untuk Kesehatan Ibu dan Anak: Graha IImu; 2011.

[12] Mahpolah, Mahdalena, Vita P. Faktorfaktor yang berhubungan dengan kebiasaan mengkonsumsi fast food pada remaja SMA Kartika V-1 Balikpapan Jombang [serial on internet]. 2016 [cited 2020 Feb 11]. Available from: academicjournal.yarsi.ac.id.

[13] Muniroh L. Faktor-Faktor Yang Mempengaruhi Status Gizi Remaja Putri Di Daerah Perkotaan dan Pedesaan di Kabupaten Jombang [serial on internet]. 2002 [cited 2020 Feb 19]. Available from:http://www.joutnal.unair.ac.di.

[14] Ika S. Faktor - Faktor yang Berhubungan Dengan Pemilihan Makanan siap saji Pada Mahasiswa Fakultas Kedokteran Dan IImu Kesehatan UIN Syarif Hidayatullah Jakarta [serial on internet]. 2013 [cited 2020 Feb 19]. Available from: repository.uinjkt.ac.id. 